Contents lists available at Џournal IICET

JPPI (Jurnal Penelitian Pendidikan Indonesia)

ISSN: 2502-8103 (Print) ISSN: 2477-8524 (Electronic)

\title{
Manfaat penerapan manajemen pengetahuan bagi kinerja dosen di masa pandemi Covid-19
}

\author{
Wahyudi Wahyudi ${ }^{1}$, Denok Sunarsi $\left.{ }^{12^{*}}\right)$ \\ ${ }^{1}$ Universitas Pamulang, Tangerang Selatan, Banten, Indonesia \\ ${ }^{2}$ Program Doktor Ilmu Manajemen, Program Pascasarjana, Universitas Pasundan, Bandung, Jawa Barat, Indonesia
}

\begin{tabular}{l} 
Article Info \\
\hline Article history: \\
Received Jun $13^{\text {th }}, 2021$ \\
Revised Jul $15^{\text {th }}, 2021$ \\
Accepted Aug $24^{\text {th }}, 2021$ \\
\hline
\end{tabular}

\section{Keyword:}

Manajemen pengetahuan

Kinerja dosen

Pandemi Covid 19

\begin{abstract}
ABSTRAK
Dinamika datang tanpa dikehendaki, sebagaimana Covid-19 ini. Sejak terjadi awal tahun 2020, pandemi secara signifikan merubah tatanan kehidupan tidak terkecuali pada Lembaga Pendidikan Tinggi. Dalam kondisi seperti ini, sikap bijak yang dapat diambil adalah beradaptasi. Artinya, lembaga memaksimalkan potensi manajemen pengetahuan guna menghadirkan model kerja yang relevan dan menjaga eksistensi kinerja. Penelitian ini bertujuan untuk mengungkap, bagaimana manajemen pengetahuan dalam implementasinya dapat menjadi salah satu solusi di dalam menjaga dan mempertahankan kinerja dosen di masa pandemi. Untuk menjawab tujuan tersebut, maka pendekatan kualitatif ditetapkan, sebagai upaya mendapatkan gambaran utuh dari fenomena yang diangkat. Penentuan unit analisis didasarkan pada kriteria yang telah ditatapkan melalui teknik purposif, kemudian dalam pembahasan hasil penelitian digunakan analisis deskriptif. Hasil penelitian dapat dikemukakan gambaran secara umum atau sedikit banyak manajemen pengetahuan membantu pihak manajemen lembaga pendidikan tinggi dalam beradaptasi dengan keadaan pandemi, khususnya dalam menjaga kinerja dosen dalam melaksanakan pendidikan. Hal ini terbukti, manajemen pengetahuan mendorong lahirnya sistem penyelenggaraan pendidikan online berbasis teknologi, sehingga kinerja dosen dalam bidang pendidikan tidak menurun. Begitu pun dalam bidang penelitian dan pengabdian, manajemen pengetahuan menginisiasi lahirnya model kerja adaptif berorientasi sistem. Artinya, walau masa pendemi covid-19 melahirkan banyak batasan dalam beraktivitas, namun dengan adanya penerapan manajemen pengetahuan, kegiatan pembelajaran, penelitian dan pengabdian yang terkait dengan tri dharma perguruan tinggi tetap berjalan sebagaimana biasanya. Tentu, keadaan ini menegaskan, bahwa manajemen pengetahuan memiliki manfaat yang besar bagi eksistensi kinerja dosen dan lembaga.
\end{abstract}

(C) 2021 The Authors. Published by IICET.

This is an open access article under the CC BY-NC-SA license

(https://creativecommons.org/licenses/by-nc-sa/4.0

\section{Corresponding Author:}

Denok Sunarsi,

Universitas Pamulang, Tangerang Selatan, Banten

Program Doktor Ilmu Manajemen, Universitas Pasundan, Bandung

Email: denoksunarsi@unpam.ac.id, denoksunarsi@mail.unpas.ac.idnok

\section{Pendahuluan}

Kehadiran wabah covid-19 telah menjadi "kanker" bagi kehidupan umat manusia di seluruh dunia. Sejak kemunculannya di awal tahun 2020 dan ditetapkan "pandemi" oleh Organisasi Kesehatan Dunia (World Health Organization/ WHO), seluruh negara menetapkan kebijakan pembatasan aktivitas (Velásquez et al., 
2021). Imbasnya, kebijakan tersebut menghambat seluruh kegiatan kehidupan, baik ekonomi, pendidikan, sosial, dan lain sebagainya. Sebagai konsekuensi logis, maka seluruh masyarakat dituntut untuk beradaptasi, tanpa terkecuali (lembaga ataupun perorangan).

Bagi lembaga pendidikan tinggi, khususnya. Kondisi di atas harus disikapi dengan bijak, yakni mencari alternatif yang memungkinkan kegiatan lembaga tetap berjalan, salah satunya menggunakan metode daring. Selama periode pandemi COVID-19, seluruh perguruan tinggi telah mengadopsi pengajaran online jarak jauh darurat, pendekatan di mana alat konferensi web, seperti Zoom dan Microsoft Teams, digunakan untuk pembelajaran online jika tidak, akan disampaikan secara tatap muka melalui campuran pendekatan pembelajaran, mengintegrasikan teknologi digital dalam berbagai cara ke dalam kampus. Pergeseran aktivitas kampus dari offline ke Online menegaskan bahwa kompetensi digital, komunikasi dan pengajaran adalah faktor kunci untuk memungkinkan sel uruh sivitas akademik beradaptasi dengan teknologi. Menurut Wang et al (2020) selama masa pandemi COVID-19, universitas mengalihkan pengajaran dari pembelajaran secara tatap muka di kampus menjadi pendekatan online atau sepenuhnya jarak jauh. Hal tersebut dilakukan sebagai jawaban atas tuntutan keadaan, dan untuk menjaga kinerja dosen serta eksistensi universitas.

Terlepas dari keadaan di atas, Purnomo, et al (2020) menjelaskan, sudah sepatutnya di abad digital atau kontemporer, seluruh perguruan tinggi bertransformasi kepada teknologi dan informasi. Maka sesungguhnya, kehadiran pandemi covid-19 hanyalah satu dari sekian faktor dari dinamika era digital, yang memicu seluruh sektor beradaptasi menggunakan teknologi. Namun dalam prosesnya, perguruan tinggi dituntut untuk secara cermat menentukan strategi yang tepat agar dapat bersaing dalam persaingan yang ketat. Untuk meningkatkan kualitas efektivitas dalam perguruan tinggi tidak hanya bergantung pada peralatan dan infrastruktur fisik yang ada, akan tetapi perguruan tinggi juga, harus mengembangkan sumber daya manusia (SDM). Kegagalan dalam mengelola sumber daya manusia akan mengakibatkan terganggunya visi perguruan tinggi. Selain itu, persaingan antar perguruan tinggi semakin ketat, dengan munculnya perguruan tinggi baru. Oleh karenanya, mengembangkan potensi SDM dan mengoptimalkan perannya adalah langkah tepat. Agarwal dan Marouf (2014) menjelaskan, ketergantungan perguruan tinggi terhadap sumber daya manusia, khususnya dosen sangat kuat. Mengingat perannya sebagai pelaku dari seluruh aktivitas lembaga, bahkan dosen sendiri merupakan sumber lahirnya pengetahuan manajemen. Fakta membuktikan, banyak organisasi yang mengalami kegagalan, bukan karena kekurangan modal atau fasilitas, melainkan kurang mampu mengelola, memberdayakan, dan mengembangkan potensi SDM yang ada.

Sejalan dengan penjelasan di atas, Butnariu dan Milosan (2012) mengemukakan, pentingnya perguruan tinggi menjadikan manajemen pengetahuan sebagai sebuah dasar pelaksanaan kerja. Hal ini akan melahirkan efektivitas dan efisiensi, di antaranya akan lahir program pelatihan, rotasi, sosialisasi, evaluasi, penetapan SOP, kebijakan dan sebagainya. Tentu, semua hal tersebut dapat memudahkan pelaksanaan tugas dan mempercepat penyelesaiannya, dengan hasil yang lebih baik. Dengan demikian kinerja dosen tetap terjaga, dalam kondisi apapun, termasuk pandemi covid-19. Dalam prakteknya di masa pandemi, manajemen pengetahuan membantu para pimpinan perguruan tinggi di dalam melahirkan sistem pembelajaran Online, sistem pelayanan administrasi akademik digital, sistem dokumentasi digital, dan sistem informasi digital. Sebagaimana yang dijelaskan oleh Husna \& Nelisa (2019), manajemen pengetahuan membantu memulihkan sistem, memperlancar operasional, mengefektifkan birokrasi, dan mendorong lahirnya percepatan di dalam pelaksanaan tugas. Dengan demikian, walau di masa pandemi, aktivitas perguruan tinggi di dalam menyelenggarakan Tri Dharma, yakni pendidikan, penelitian, dan pengabdian kepada masyarakat tetap berjalan sesuai peraturan dan keadaan. Al-hasil, kinerja lembaga tetap terjaga. Menurut Ramachandran et al (2013) manajemen pengetahuan perguruan tinggi berjalan dengan baik dengan manajemen pengetahuan membuat setiap dosen dapat memahami tugasnya masing-masing. Di sini juga terlihat bagaimana dosen meminimalisir kesalahan yang terjadi dalam pekerjaannya masing-masing.

Fakta menarik tentang penerapan manajemen pengetahuan selama masa pandemi adalah, lembaga dan seluruh SDM yang ada menjadi lebih siap di dalam menghadapi perubahan, dari model kerja luring menjadi daring, baik dalam bidang pendidikan, penelitian, maupun pengabdian. Dalam arti siap, manajemen pengetahuan mendorong jajaran manajemen untuk melahirkan kebijakan-kebijakan teknis yang relevan dengan keadaan, dan mendorong seluruh pihak untuk mempelajari sistem baru, sehingga sistem kerja daring dapat berjalan tanpa suatu kendala berarti. Sebagai konsekuensinya, manajemen pengetahuan mengacu pada pemanfaatan penuh informasi dan data secara eksplisit dan bentuk implisit (Chatterjee, et al., 2020). Artinya, secara definitif manajemen pengetahuan memerlukan pandangan sumber daya manusia sebagai pelaksana, sehingga antara kepentingan lembaga yang dibatasi oleh keadaan tidak terganggu secara teknis, karena SDM telah siap untuk berkembang dan mengikuti sistem baru (Ramachandran et al, 2013). Dengan demikian, penting bahwa perguruan tinggi mengidentifikasi kemampuan teknologi dan infrastruktur yang secara langsung berdampak positif terhadap kinerja perguruan tinggi. Pemimpin manajemen pengetahuan dapat 
bertindak sebagai panutan keterlibatan dalam perencanaan, komunikasi, dan pembinaan (Tan et al, 2013). Jajaran manajemen dapat memastikan bahwa semua SDM disadarkan tentang arti kualitas bagi organisasi dengan menunjukkan komitmen tinggi melalui sikap inisiatif dan keterlibatan aktif.

Ketika manajemen atas menghabiskan waktu untuk kualitas kegiatan, itu memberikan bukti kepemimpinan yang mengilhami orang lain untuk melakukan bagian mereka. Proses manajemen pengetahuan didefinisikan sebagai sejauh mana pendidikan tinggi menciptakan, berbagi, dan memanfaatkan sumber daya pengetahuan melintasi batas-batas fungsional (Chourides et al., 2020)) menganggap bahwa manajemen pengetahuan utama terletak pada aliran organisasi termasuk:pengembangan pengetahuan inovatif, distribusi pengetahuan saat dibutuhkan, penyimpanan pengetahuan untuk masa depan dan bidang aplikasi dan integrasi pengetahuan dalam keseluruhan organisasi. Tujuan utama dari penelitian ini adalah untuk menemukan apa yang ada. Untuk menjawab pertanyaan di atas, tujuan yang ingin dicapai adalah untuk menganalisis strategi manajemen Pengetahuan untuk peningkatan kinerja dosen.

\section{Metode}

Diperlukan tindakan ilmiah di dalam mengungkapkan fenomena tersebut, dan penelitian ini menetapkan kualitatif sebagai dasar ilmiah. Namun, alasan sesungguhnya dibalik keputusan ini adalah relevansi tujuan penelitian yang hendak dicapai, yakni menguak gambaran terkait manajemen pengetahuan yang diterapkan pada objek penelitian, melalui wawancara mendalam kepada unit analisis yang ditetapkan sebagai informan. ruang lingkup pertanyaan yang diajukan mencakup kinerja dosen bidang pendidikan, bidang penelitian, dan bidang pengabdian berbasis manajemen pengetahuan. Daftar pertanyaan disusun secara sistematis dan aktual, sehingga informan dapat mengungkapkan keadaan sesungguhnya.

Wilayah penelitian adalah Kopertis IV Provinsi Banten, namun secara spesifik objek penelitian ditetapkan dengan kriteria sebagai berikut: 1) Lembaga pendidikan tinggi berbentuk universitas; 2) Berada di bawah LLDIKTI 4 Provinsi Banten; 3) Selama pandemi (2020-2021) universitas telah menggunakan sistem pembelajaran secara daring; 4) Selama pandemi (2020-2021) universitas menerapkan pelayanan akademik Online; 5) Selama pandemi (2020-2021) universitas menerapkan sistem teknologi pendukung penelitian dan pengabdian; dan 6) Selama pandemi (2020-2021) universitas menerapkan sistem administrasi online.

Teknik sampel purposif digunakan sebagai landasan teoritis dalam menetapkan unit analisis sebagai informan, sampel yang dijadikan sumber data diseleksi berdasarkan kriteria, di antaranya: 1) Masa kerja minimal 10 tahun; 2) Memiliki jabatan fungsional minimal lector; 3) Tingkat pendidikan S3; 4) Terlibat aktif dalam kegiatan internal dan eksternal universitas; 5) Memahami budaya kerja universitas; 7) Bukan pejabat structural; dan 8) Berstatus sebagai tim pengembang lembaga, minimal di tingkat program studi.

Berdasarkan kriteria di atas, maka ditetapkan 8 koresponden yang dijadikan sumber informasi, dengan karakteristik sebagai berikut:

Tabel 1. Profil Partisipan

\begin{tabular}{llcccl}
\hline No & Jenis Kelamin & $\begin{array}{c}\text { Masa Kerja } \\
\text { (Tahun) }\end{array}$ & $\begin{array}{c}\text { Jabatan } \\
\text { Fungsional }\end{array}$ & $\begin{array}{c}\text { Tingkat } \\
\text { Pendidikan }\end{array}$ & Keterlibatan di Lembaga \\
\hline 1 & Pria & 14 & Lektor Kepala & S3 & Pengembang Fakultas \\
2 & Wanita & 16 & Lektor Kepala & S3 & Pengembang Fakultas \\
3 & Wanita & 11 & Lektor & S3 & Pengembang Prodi \\
4 & Pria & 18 & Lektor & S3 & Pengembang Prodi \\
5 & Pria & 11 & Lektor & S3 & Pengembang Prodi \\
6 & Wanita & 10 & Lektor & S3 & Pengembang Prodi \\
7 & Pria & 14 & Lektor & S3 & Pengembang Prodi \\
8 & Wanita & 11 & Lektor & S3 & Pengembang Prodi \\
\hline
\end{tabular}

(Sumber: Data penelitian, 2021)

Data yang digunakan dalam penelitian ini terdiri dari dua jenis data, yaitu data primer dan data sekunder. Analisis data primer adalah sumber utama untuk penelitian ini. Data primer dikumpulkan dari wawancara mendalam dan observasi, dan data sekunder diperoleh melalui buku teks, survei, laporan, surat kabar, majalah,artikel, dan rekaman video. Menurut Liaw et al (2010), Leung et al (2015) menyatakan bahwa analisis data kualitatif dilakukan secara interaktif dan terus-menerus sampai selesai, sehingga datanya jenuh. Menurut Liaw et al (2010), Leung et al (2015) dalam pengujian keabsahan data, menggunakan metode 
penelitian kualitatif, meliputi uji kredibilitas, uji transferabilitas, uji ketergantungan dan uji kesesuaian. Dalam penelitian ini, validitas dan reliabilitas data diuji dengan menggunakan triangulasi.

\title{
Hasil dan Pembahasan
}

Berdasarkan hasil wawancara secara terstruktur terhadap 8 orang dosen dapat dirangkum data sebagai berikut:

Informan 1 adalah seorang dosen fakultas teknik universitas swasta

Menurut informan 1 pimpinan selalu memberikan semangat kepada karyawan. Setiap bulan mereka melakukan briefing dengan pimpinan dengan semua divisi.

\begin{abstract}
Informan 2 adalah seorang dosen fakultas ekonomi universitas swasta
Informan 2 telah bekerja selama 8 tahun. Baginya, manajemen pengetahuan sudah ada di perguruan tinggi. Jenis strategi manajemen pengetahuan pada pendidikan tinggi harus mencerminkan strategi kompetitif internal dan strategi yang dipilih harus menciptakan nilai bagi pelanggan dan keuntungan pendidikan tinggi dan harus fokus pada bagaimana dosen memberikan pada nilai, diferensiasi dan kecepatan ,pendekatan untuk mempelajari strategi manajemen pengetahuan telah mengandalkan pandangan berbasis sumber daya dan pandangan berbasis pengetahuan tentang isu-isu strategis dalam manajemen pengetahuan. Manajemen Pengetahuan sebagai strategi bisnis, transfer pengetahuan dan praktek terbaik, pengetahuan yang berfokus pada pelanggan, tanggung jawab pribadi untuk pengetahuan, inovasi dan penciptaan pengetahuan, dan kolaborasi untuk pengetahuan baru adalah enam strategi manajemen pengetahuan. Informan 2 mengatakan bahwa implementasi strategis manajemen pengetahuan di perguruan tinggi adalah dengan cara setiap pagi mereka selalu memberikan pengarahan kepada dosen dan memberikan semangat kepada mereka, dikarenakan menurut informan 2 mereka yang benar-benar mereka berhadapan langsung dengan mahasiswa . jadi informan 2 mengatakan setiap dua minggu sekali bertemu dengan dosen . Dalam pertemuan banyak di antaranya menanggapi setiap pertemuan dan berusaha mencapai target kinerja yang telah ditentukan.
\end{abstract}

\section{Informan 3 adalah seorang dosen fakultas pendidikan universitas swasta}

Menurut informan 3 implementasi suatu perguruan tinggi strategi manajemen yaitu di mana informan 3 melihat skill terlebih dahulu dan menempatkan posisi pekerjaan yang baik di mana dan melihat latar belakang pendidikan. Manajemen pengetahuan adalah keharusan untuk budaya organisasi. Lembaga pendidikan termasuk yang terakhir menerapkan Prinsip dan program manajemen pengetahuan dan menyarankan agar akademik meningkatkan kemampuannya untuk melayani pemangku kepentingan internal dan eksternal. Manajemen pengetahuan yang efektif juga dapat meningkatkan kemampuan universitas untuk terlibat dalam pembangunan ekonomi regional, seperti yang ditunjukkan oleh upaya universitas-universitas untuk mengintensifkan peran keterlibatan regional .Informan 3 berpendapat bahwa sosialisasi, eksternalisasi, kombinasi dan internalisasi semua telah dilakukan dan dilaksanakan. Di mana setiap minggunya diberikan diskusi dengan tim untuk meningkatkan kinerja dosen. Jadi informan 3 mengatakan bahwa mereka menerapkan setiap proses manajemen pengetahuan terlebih dahulu, jadi mereka dapat memahami setiap karakter pelanggan. Setiap minggu rapat pendidikan tinggi dan bertanya tentang prestasi yang ada. Menurut informan 3 penerapan proses manajemen pengetahuan dalam perguruan tinggi sudah ada, namun belum terarah dengan baik.

\section{Informan 4 adalah seorang dosen fakultas hukum universitas swasta}

Informan 4 sudah bekerja selama 10 tahun. Menurut informan 4 manajemen pengetahuan sudah ada dan sangat standar. Universitas cenderung untuk memainkan peran ekonomi utama dalam komunitas mereka berfungsi sebagai pemberi kerja, sebagai sumber pengetahuan teknologi,dan sebagai sumber pengembangan sumber daya manusia bagi individu dan bisnis. Melihat pengetahuan sebagai perkembangan faktor dapat bermanfaat bagi universitas dan masyarakat yang mereka layani melalui pembentukan daya saing regional keuntungan. Faktanya, modal manusia yang langka, berharga, dan sulit untuk ditiru mungkin saja sumber utama keunggulan kompetitif yang berkelanjutan dalam masa depan. Mengembangkan sumber daya manusia di dalam universitas dan mempersiapkan mahasiswa untuk memasuki situasi pembelajaran organisasi di eksternal lingkungan mungkin menjadi mandat tertinggi untuk yang lebih tinggi pendidikan. Manajemen pengetahuan diterapkan melalui berbagi pengetahuan dan belajar untuk setia pada pekerjaan dosen sendiri. Informan 4 mengatakan bahwa setiap strategi implementasi manajemen Pengetahuan dilakukan dengan baik, dan dilakukan secara maksimal di mana setiap strategi dapat menguntungkan pendidikan tinggi. Informan 4 juga mengatakan bahwa setiap 4 poin sosialisasi, eksternalisasi, kombinasi,internalisasi pendidikan tinggi berjalan dengan baik.

\section{Informan 5 adalah seorang dosen fakultas ekonomi universitas swasta}

Informan 5 sudah bekerja selama 11 tahun. Menurut informan 5 manajemen pengetahuan sudah dimiliki oleh perguruan tinggi, namun pengetahuan pendidikan tinggi sudah belum sempurna. Manajemen pengetahuan 
tentu saja menarik perhatian, tetapi sebagian besar literatur setuju bahwa jika ada demonstrasi konsekuensi dari adopsi manajemen pengetahuan sebagai konsep atau implementasi di seluruh pendidikan tinggi. Di sisi lain, ada kesepakatan bahwa masyarakat berbasis pengetahuan dan organisasi-organisasi yang akan berhasil bertahan dalam masyarakat adalah mereka yang dapat mengidentifikasi, menilai, menciptakan, dan mengembangkan aset pengetahuan. Informan 5 mengatakan bahwa manajemen pengetahuan dalam implementasi strateginya adalah di mana mereka fokus pada dosen. Memang menurut informan 5 di perguruan tinggi tidak ada product knowledge atau training pengetahuan, tetapi berdasarkan katalog yang ada. Jadi menurut informan 5 proses di dalam pendidikan tinggi, tidak terlalu langsung dan tidak maksimal. Menurut informan 5 dari setiap proses yang ada, perguruan tinggi sudah melaksanakan tetapi belum terlalu fokus. Informan 5 mengatakan bahwa manajemen pengetahuan sangat penting, karena tanpa manajemen pengetahuan perguruan tinggi tidak akan berjalan dengan baik.

\section{Informan 6 adalah seorang dosen fakultas pendidikan universitas swasta}

Menurut informan 6 implementasi strategis manajemen pengetahuan mulai dari sosialisasi, eksternalisasi, kombinasi dan internalisasi selalu dilakukan, sedangkan sosialisasi selalu mereka temui bersama, tentang perkuliahan yang mereka capai. Konsep manajemen pengetahuan untuk proses, sistem, struktur dan peran dalam pendidikan tinggi, dengan tujuan untuk mengatur dan agenda untuk masa depan. Universitas memang memiliki tingkat manajemen pengetahuan yang signifikan kegiatan, dan penting untuk mengenali ini, dan menggunakannya sebagai dasar untuk pengembangan lebih lanjut, daripada menciptakan paradigma baru. Serangkaian yang tidak berhubungan kegiatan berbasis pengetahuan tidak cukup. Universitas dan stafnya harus mengakui dan menanggapi peran mereka yang berubah dalam masyarakat berbasis pengetahuan. universitas membutuhkan untuk secara sadar dan eksplisit mengelola proses yang terkait dengan penciptaan aset pengetahuan mereka, dan untuk mengenali nilai modal intelektual mereka untuk melanjutkan peran dalam masyarakat, dan dalam lingkup yang lebih luas pasar global untuk pendidikan tinggi. Informan 6 juga mengatakan bahwa eksternalisasi di dalam perguruan tinggi telah dilakukan dengan baik, serta kombinasi dan internalisasi selalu dilakukan. Apalagi menurut informan 6 harus bisa memahami empat poin strategis implementasi manajemen pengetahuan.

\section{Informan 7 adalah seorang dosen fakultas teknik universitas swasta}

Menurut informan 7 di perguruan tinggi tersebut sudah memiliki manajemen pengetahuan. Informan 7 mengatakan bahwa ketika dalam suatu pekerjaan harus ada pelatihan dan juga harus mengetahui pengetahuan yang dilakukan dalam pekerjaan tersebut. Universitas harus merangkul semua staf dan siswa di universitas, dan tidak hanya menjadi tambahan beban atau agenda yang ditetapkan oleh manajemen senior. Untuk mencapai tingkat kepemilikan ini penyematan penuh pengetahuan manajemen akan menjadi proses evolusi. Untuk menilai tantangan yang lebih tinggi dihadapi institusi pendidikan dalam menanamkan manajemen pengetahuan, empat jenis manajemen pengetahuan tujuan sebagai lensa untuk melihat institusi pendidikan tinggi: penciptaan dan pemeliharaan repositori pengetahuan; meningkatkan akses pengetahuan; meningkatkan lingkungan pengetahuan; dan, menilai pengetahuan. Menurut informan 7 implementasi strategis pengelolaan pengetahuan harus ada karena dapat memudahkan kita untuk melakukan pekerjaan dengan baik. Masingmasing strategis implementasi manajemen pengetahuan dari 4 hal ini di mana mereka melakukan setiap pertemuan dalam 3 bulan untuk mengetahui kinerjanya masing-masing

\section{Informan 8 adalah seorang dosen fakultas pendidikan universitas swasta}

Menurut Informan 8 di pendidikan tinggi sudah ada manajemen pengetahuan. Informan 8 mengatakan strategi penerapan manajemen pengetahuan adalah saling berbagi pengalaman dan bagaimana menjelaskan bagaimana memosisikan sebagai kolektor, yang harus sopan dan tidak kasar. Keempat strategi manajemen pengetahuan tersebut semuanya sangat penting, apalagi sosialisasi untuk membangun kinerja dan pimpinan dapat mengetahui kendala-kendala yang terjadi di lapangan dan mencari solusinya. untuk mencapai setiap target yang ada. Dengan manajemen pengetahuan dimungkinkan untuk mengatasi masalah administrasi publik seperti: Ketika ada kebutuhan akan keahlian atau keterampilan tertentu dan tidak ada staf yang memiliki pengetahuan seperti itu. Ketika solusi untuk suatu masalah membutuhkan beberapa pengalaman tetapi orang yang memiliki pengalaman ini hilang. Saat mencocokkan orang (artinya kemampuannya) dan pekerjaan tidak bekerja secara efisien saat optimal pencocokan antara posisi dan spesifik, objektif kemampuan. Ketika sebuah organisasi memutuskan untuk menerapkan kebijakan staf pelatihan, tetapi kebutuhan pelatihan, yang mencerminkan kesenjangan pengetahuan tidak diketahui dan belum didokumentasikan.

Penelitian ini bertujuan untuk mengetahui penerapan proses manajemen pengetahuan di perguruan tinggi, manajemen Pengetahuan sangat penting dalam sebuah organisasi, untuk mengetahui seberapa sukses mereka menjalankan bisnis. Menurut Wang et al (2020), Velásquez et al (2021) manajemen pengetahuan adalah aset penting dari organisasi mana pun, karena modal intelektual untuk mendapatkan keunggulan kompetitif yang berkelanjutan di era persaingan yang ketat ( Tan et al, 2013). 
Strategi manajemen pengetahuan dalam merencanakan tindakan yang diperlukan organisasi pendidikan adalah memotivasi perilaku: Untuk memotivasi berbagi pengetahuan, mengomunikasikan dengan jelas strategi dan tujuan manajemen pengetahuan kepada pemangku kepentingan dan memberikan insentif atau penghargaan untuk mencapai perilaku berbagi pengetahuan yang diinginkan. Mendorong Jaringan: Bantu dosen berbagi pengetahuan dengan memberikan peluang untuk kolaborasi lintas organisasi dan melalui penggunaan perangkat lunak sosial. Kumpulkan pengetahuan, jaga agar informasi mengalir melalui jalur manajemen pengetahuan. Secara konsisten menangkap, menganalisis, dan mengkodifikasi pengetahuan ini dan kemudian membuatnya tersedia untuk pencarian dan dapat diambil kembali. Analisis dan Aktifkan. Evaluasi pengetahuan baru yang cermat untuk memastikan akurasi adalah kuncinya. Kemudian, menganalisis pengetahuan untuk mencari pola, tren atau koneksi yang dapat mengarah pada pengetahuan baru. Pengetahuan yang dikumpulkan harus dikodifikasikan agar lebih mudah dicari dan memungkinkan pemberian tag, templating, dan katalogisasi. Menyebarluaskan: Pengetahuan yang ditangkap tidak memiliki nilai kecuali pengguna potensial tahu itu tersedia. Rencanakan untuk memberi tahu pengguna tentang pengetahuan baru atau yang diperbarui dan di mana menemukannya melalui saluran yang paling sering berinteraksi dengan pengguna, termasuk email, buletin, situs web, atau jejaring sosial. Menerapkan manajemen pengetahuan Berbasis Permintaan: Strategi manajemen pengetahuan yang efektif termasuk merangsang permintaan akan pengetahuan. Dorong pengguna untuk mengajukan pertanyaan, mengirimkan pertanyaan, dan mencari. Dengan cara ini, akan dapat mengidentifikasi konten yang dibutuhkan dan lebih efisien dalam menangkap pengetahuan. Augment Through Technology: Bawa strategi manajemen pengetahuan ke level selanjutnya. Pertimbangkan bagaimana komputasi kognitif dan kecerdasan buatan (AI) dapat meningkatkan kemampuan manusia untuk observasi, analisis, pengambilan keputusan, pemrosesan, dan respons terhadap orang dan situasi.

Proses terkait dengan proses menangkap nilai-nilai pengetahuan ke dalam suatu media dan kemudian dibagikan kepada individu yang lain untuk digunakan kembali. Teknologi adalah aspek ketiga dari keberadaan alat batin yang mendukung orang-orang dan proses berjalan dengan benar, jadi dengan manajemen pengetahuan, setiap pekerjaan dapat berjalan dengan baik dan terarah. Informan 1, 2, 4, 6 mengatakan bahwa manajemen pengetahuan di dalam perguruan tinggi merupakan suatu hal penting yang harus dilaksanakan, karena tanpa manajemen pengetahuan, perguruan tinggi akan berjalan dengan baik. Menurut Chourides et al.(2020), García et al (2010) dalam manajemen pengetahuan ini harus mencakup setiap sumber daya manusia dan manajemen TI yang bertujuan untuk mencapai organisasi perguruan tinggi yang lebih baik, sehingga mampu memenangkan persaingan bisnis. Informan 3,5,7,8 memiliki hal yang sama pendapat atau jawaban yaitu melalui penerapan manajemen pengetahuan mereka mendapatkan lebih banyak pengetahuan, dan memudahkan mereka dalam bekerja. Karena, mereka tidak hanya belajar tentang manajemen pengetahuan, tetapi mereka juga mencoba menerapkan manajemen pengetahuan pada setiap dosen dengan menceritakan pengalamannya masing-masing. Menurut Ramachandran et al (2013) dan Shoham et al (2009) proses dari manajemen pengetahuan dalam suatu pendidikan tinggi sangat penting karena dapat membantu perguruan tinggi berjalan, setiap informan 1,2,3,4,5,6,7,8 mengatakan bahwa proses di pendidikan tinggi tidak terlalu terarah karena perguruan tinggi masih menggunakan alat kerja sistem yang diimplementasikan tanpa menggunakan struktur yang ada. Oleh karena itu informan 1-8 mengatakan pelaksanaan proses belum maksimal, setiap kali sharing knowledge di perguruan tinggi dilakukan setiap bulan bersama pimpinan dalam mencari tahu kendala yang terjadi di lapangan. Informan 1,2,3,4,5,6,7,8 mengatakan bahwa setiap proses manajemen pengetahuan yang dilakukan penelitian disampaikan sangat penting, dan mereka berharap di pendidikan tinggi mereka juga dapat melakukannya sesuai dengan struktur yang ada. Sehingga dalam pendidikan tinggi juga telah menggunakan teknologi dalam proses pekerjaannya, sehingga masing-masing ada proses mungkin berjalan dengan baik, tetapi itulah sebabnya di pendidikan tinggi menerapkan proses manajemen pengetahuan tidak terlalu maksimal.

\section{Simpulan}

Dari semua jawaban di atas, terlihat bahwa manajemen pengetahuan memberikan manfaat bagi Kinerja dosen. Tidak hanya itu, karyawan menyatakan manajemen pengetahuan sangat penting dan perlu selalu diimplementasikan di wilayah kerja karena dapat membantu perkembangan perguruan tinggi Ada 4 faktor utama yaitu sosialisasi, eksternalisasi, kombinasi, dan internalisasi yang menjadi tolak ukur kinerja dosen di perguruan tinggi. Dengan pengaruh positif dari keempat faktor tersebut, perguruan tinggi akan memiliki kinerja yang baik dan akan menjadi lebih baik dari waktu ke waktu. Penerapan proses manajemen pengetahuan mengembangkan kinerja dosen karena pada hasil wawancara, secara umum semua informan menyatakan bahwa manajemen pengetahuan memberikan dampak baik bagi kinerja dosen. 
Beberapa rekomendasi yang diusulkan dan ditemukan dengan penelitian ini untuk perguruan tinggi harus menerapkan manajemen pengetahuan harus maksimal, karena manajemen pengetahuan ini sangat penting dalam menjalankan perguruan tinggi dan tidak akan kalah bersaing dengan perguruan tinggi.. Bagi peneliti disarankan untuk melakukan penelitian pada perguruan tinggi di wilayah lainnya dengan metode penelitian yang lainnya penelitian mendalam tentang seberapa efektif manajemen pengetahuan di perguruan tinggi, sehingga manajemen pengetahuan dapat dipahami dan pendidikan tinggi memiliki kesadaran akan pentingnya manajemen pengetahuan dan menganggap manajemen pengetahuan merupakan aset yang sangat penting dalam kesuksesan pada perguruan tinggi.

\section{Referensi}

Agarwal, N. K., \& Marouf, L. N. (2014). Initiating manajemen pengetahuan in colleges and universities: A template. International Journal of Knowledge Content Development \& Technology, 4(2), 67-95.

Butnariu, M., \& Milosan, I. (2012). Preliminary assessment of manajemen pengetahuan in universities. Procedia-Social and Behavioral Sciences, 62, 791-795.

Chatterjee, S., Ghosh, S. K., \& Chaudhuri, R. (2020). Manajemen pengetahuan in improving business process: an interpretative framework for successful implementation of AI-CRM-KM system in organizations. Business Process Management Journal, 26(6), 1261-1281.

Chourides, P., Longbottom, D., \& Murphy, W. (2003). Excellence in manajemen pengetahuan: an empirical study to identify critical factors and performance measures. Measuring business excellence.

Deliu, D. (2020). The Intertwining between Corporate Governance and Manajemen pengetahuan in the Time of Covid-19 â€"A Framework. Journal of Emerging Trends in Marketing and Management, 1(1), 93-110.

Hoq, K. M. G., \& Akter, R. (2012). Manajemen pengetahuan in universities: Role of knowledge workers. Bangladesh Journal of Library and Information Science, 2(1), 92-102.

Husna, N., \& Nelisa, M. (2019). Upaya Penerapan Manajemen Pengetahuan dI Perpustakaan STIKES ALifah Padang. Ilmu Informasi Perpustakaan dan Kearsipan, 8(1), 263-268.

Leung, N. K., Shamsub, H., Tsang, N., \& Au, B. (2015). Improving the learning experience of tertiary students in a lecture hall: the implementation of a manajemen pengetahuan methodology in an offshore campus of an Australian university. International Journal of Innovation and Learning, 17(4), 409-424.

Liaw, S. S., Hatala, M., \& Huang, H. M. (2010). Investigating acceptance toward mobile learning to assist individual manajemen pengetahuan: Based on activity theory approach. Computers \& Education, 54(2), 446-454.

Mohd Ghazali, M., Nor Azirawani, M., Norfaryanti, K., \& Mar Idawati, M. (2007). The application of manajemen pengetahuan in enhancing the performance of Malaysian universities. Electronic journal of manajemen pengetahuan, 5(3), 301-312.

Purnomo, A., Sudirman, A., Hasibuan, A., Sudarso, A., Sahir, S. H., Salmiah, S., ... \& Simarmata, J. (2020). Dasar-Dasar Kewirausahaan: Untuk Perguruan Tinggi dan Dunia Bisnis. Yayasan Kita Menulis.

Ramachandran, S. D., Chong, S. C., \& Wong, K. Y. (2013). Manajemen pengetahuan practices and enablers in public universities: A gap analysis. Campus-Wide Information Systems.

Shoham, S., \& Perry, M. (2009). Manajemen pengetahuan as a mechanism for technological and organizational change management in Israeli universities. Higher education, 57(2), 227-246.

Tan, C. N. L., \& Md. Noor, S. (2013). Manajemen pengetahuan enablers, knowledge sharing and research collaboration: a study of manajemen pengetahuan at research universities in Malaysia. Asian Journal of Technology Innovation, 21(2), 251-276.

Velásquez, R. M. A., \& Lara, J. V. M. (2021). Manajemen pengetahuan in two universities before and during the COVID-19 effect in Peru. Technology in Society, 64, 101479.

Wang, W. T., \& Wu, S. Y. (2020). Manajemen pengetahuan based on information technology in response to COVID-19 crisis. Manajemen pengetahuan Research \& Practice, 1-7. 